\title{
Informal micro-enterprises: What impact does the business environment have on the decision of formalization?
}

\author{
El hassania Rahou ${ }^{1, *}$ and Ahmed Taqi ${ }^{2}$ \\ ${ }^{1}$ Laboratoire des Problèmes Contemporains Economiques, Juridiques \& Sociaux, Faculté des SJES de tétouan, Maroc \\ ${ }^{2}$ Université Abdelmalek Essaâdi, Faculté des SJES de Tétouan, Département des Sciences de Gestion, Maroc.
}

\begin{abstract}
This work studies the impact of the perception of the constraint imposed by the business environment on the disposition of Moroccan informal micro-enterprises to move to the formal sector. We test the hypothesis that this disposition to formalize is based on a profit maximization model consisting in comparing the advantages and costs of setting up in the formal and informal sectors. Using data collected from 100 informal micro-entrepreneurs and using step-by-step logistic regression, we find that the decision of microenterprises to structure themselves is dependent on the socio-economic characteristics of the country in question (macroeconomic context, legal and business regulations, etc.). In addition, we find that the desire for formalization is negatively impacted by perceptions linked to the unavailability of basic infrastructure (electricity, water, telephone, etc.), access to finance, access to premises, access to public contracts, access to information as well as the burden of administrative procedures. These results suggest that improving the business environment and general governance could further drive microenterprises to take the step towards formal entrepreneurship, thus providing a broader tax base and other benefits to society in the future.
\end{abstract}

\section{Introduction}

The informal sector in Morocco is important, both in terms of number of businesses and contribution to GDP. Indeed, an average annual increase of 19,000 informal production units (IPU) is estimated, as well as the added value created by these units represents $12.6 \%$ of the national added value [10] .In addition, in recent years, informality has grown considerably, fueled by various factors. De Soto (1989) concluded that informal actors remained outside the formal sector due to the cost imposed by the country's regulatory structure.

Most authors working in the informal sector argue that companies locate in this sector because the manager (entrepreneur) believes that the benefits of informality outweigh the costs [11]. Similarly, [12] have set up a formalization model around costs and benefits in each investment climate (formal and informal). They then assessed approaches to encourage formalization in this paradigm and made recommendations for specific actions. In our analysis, we test this hypothesis using new data at the microenterprise level in Morocco.

In this paper, we draw on a number of studies to examine the decision-making process at the individual microenterprise level. We test the hypothesis that companies decide to settle in the formal or informal sector on the basis of a cost-benefit analysis, which itself depends on several aspects of the business environment.

\section{Informality: Theoretical Considerations}

The informal sector is currently a burdensome reality whether at the level of developing economies or at the global level [26].

One of the difficulties encountered by the researcher on the informal sector is the lack of a widely accepted definition of this sector. Almost jointly, the concept of informality emerged in 1971 on both ends of the African continent : in Ghana, with the notion of "informal income opportunities" (Hart, 1971, published in 1973), and in Kenya by the famous "Kenya report" published by the International Labor Office (ILO) on the urban employment situation in Nairobi [22]. In 1972, this organization defined informal sector enterprises based on the following multiple criteria : family business ownership, small scale of operations, labor-intensive techniques, low educational level of entrepreneurs, accessible markets and use of local resources [27]. From that date, the concept of the "informal sector" brought together activities which are no longer homogeneous and which are carried out, at least partially, outside of public regulations (production crafts, personal services, business services, petty trading, etc.) [3].

The notion of informality, introduced by Hart in 1971, was based on the individual and it has been as a source for many sociological and anthropological studies in Africa and elsewhere. As for the one introduced by the ILO, it is

\footnotetext{
*Corresponding author: rahouhassania@gmail.com
} 
based on the establishment or the company and inspired by numerous studies and surveys carried out by the ILO in Africa, Latin America and Asia. For [5], these two conceptions put the state at the center of the emergence of small informal activities, either by the intrinsic nature of a nascent capitalism, or by the obstacles which prevent private initiative from flourishing.

Following the 15th International Conference of Labor Statisticians, the ILO adopted in 1993 the point of view of practitioners by considering the informal sector as a component of the institutional household sector within the United Nations system of national accounts. In this context, this expression is assimilated to sole proprietorships not keeping full accounts and not being registered. In other words, this informal sector includes the self-employed working on their own account, alone or with the help of unpaid family members, and can be extended to micro and small enterprises employing less than five paid employees (there is no explicit threshold in 1993 which is implicitly less than 10 employees and is explicitly set at less than 5 employees by the Delhi group).[3]. It is on the basis of this conference that the non-registration of the person (in the labor or social security registers) or the non-registration of the company (in the tax or commercial registers) became a criterion basis for defining or measuring informality [5].

In Morocco, the definition of the informal sector is that of the High Commission for Planning (HCP) for which «this sector includes all non-agricultural production units that carry out production activities of goods and services without complying with the statutory and accounting provisions to which companies operating in the national economy are subject ». As such, in 2013, this sector employed 2.4 million of people, i.e. $36 \%$ of people working in Morocco (excluding agricultural employment), thus, with 103.346 billion $\mathrm{DH}$ and a rate of $56 \%$ of production, added value created by informal production units (IPU) represents $12.6 \%$ of the national added value [10]. In Morocco, this sector is also characterized by a certain heterogeneity comprising both small production activities like (crafts, etc.), service activities (repair, mechanics, plumbing, guarding, etc.) and trade activities (food, clothing, etc.) and the building [1].

Recently, management literature considers the informal sector as economic activities that are outside formal institutional boundaries (i.e. illegal) but within informal institutional boundaries (i.e. activities which remain legitimate for a large part of society) (Webb and al. , 2009). Phenomena falling within the scope of this definition include the use of undocumented workers, counterfeiting, the sale of unregulated pharmaceuticals, unregistered and / or tax-evading businesses, hacking, circumvention of environmental regulations and / or work, and often street selling. This definition from the management literature is consistent with De Soto's (1989) description of the informal economy, which includes illegal economic activities but excludes "antisocial in intention" activities, such as cocaine distribution, human trafficking and bank robbery.

This definition is also widely compatible with that of Portes and his colleagues (Centeno and Portes, 2006;
Portes, 1994; Portes and Haller, 2005; Portes and Sensenbrenner, 1993), these authors define informal activities as the production of legal goods according to processes that are not entirely legal. Specialists who drew on the definition of Portes routinely examined unregistered activities and circumvention of environmental and / or labor regulations [28]. However, other researchers provide more precise definitions of informality. Nichter and Goldmark (2009) simply define informality as unregistered economic activities that produce legal products.

In this paper, we consider the informal sector as all the activities that take place, in part or in full, outside of penal, social and fiscal legislation or that escape national accounts, economic and social policy, and therefore to any state regulation. The choice of this definition is justified by the fact that it fits the context in which we are studying this sector, namely informal entrepreneurship.

The different conceptions of informality explain the diversity of the ways used to collect data on the informal sector, as well as the difficulty of their comparability at the international level.

\section{Influence of the business environment on the decision of formalization}

The entrepreneurial conversion of an informal enterprise into a formal activity can only be motivated by the will of the entrepreneur who wishes it or who feels obliged by the business environment in which he operates.

Building on the influential work of de Soto (1989), many recent studies examining the decision to formalize firms point out that unequally enforced and binding regulations as well as corruption (Friedman et al, 2000) and entry costs (Djankov et al., 2002; Auriol and Walters 2005; Bruhn 2013) are associated with (in) formal economic behavior. Likewise, (WB 2011) observes that regressive compliance costs can determine the levels of business compliance. Alcãzar et al. (2010) find that in Peru the offer of a subsidy for the cost of obtaining a municipal license leads informal businesses to obtain it by 10 to $12 \%$.

Indeed, ease of registration is a major obstacle to formalization (de Soto 1989). This covers the number of procedures, timeframes and costs involved in securing registration with various regulatory authorities, such as the tax, social security and labor departments. The idea is that by simplifying registration, for example by reducing the costs and / or time required to register a business, or by using a one-stop-shop to eliminate the need to visit multiple administrations (for example, Williams and Renooy 2013), formalization will increase. Others, however, show that simplifying registration does not always lead to formalization (Bruhn and McKenzie 2013).

Alternatively, informality can be a wise choice for entrepreneurs who obtain competitive advantages in terms of costs [8]cited by [13]. With this in mind the study carried out by [9] to analyze the impact of the elimination of the initial fixed registration costs on the decision of informal businesses to officially operate in Colombia, showed that " a substantial reduction in fixed formal 
operating costs does not play a key role in a company's decision to formalize or not, since this reduction did not have a lasting effect on the decision to operate in the formal sector. A considerable number of the firms in the study chose to go formal while they were free, but later, when called upon to pay a relatively small fee, they decided to return to the informal sector. In this sense, this study corroborates the results of De Mel et al. (2013), since it suggests that firms remain informal, not because expensive entry costs prevent them from functioning officially, but because they perceive that the benefits of formality are modest.

In previous publications (Tokman, 2007 ; [8];[26] ; [14]; [18]; [19]; [4]; [16] have considered the complexity and inefficiency of the administration as decisive elements in the decision to formalize informal operators. these are in particular administrative red tape, the weight of tax and social contributions, number of types of tax and their method of calculation, difficulty of access to financing, mismanagement and efficient use of collective resources, inaccessibility to basic public services, excessively high costs of registration services, remoteness of administrative services, etc.

Several studies show that many challenges hamper the growth of micro-enterprises, insufficient access to formal credit is one of the main bottlenecks for these units. Morocco is no exception, despite favorable credit policies, many small Moroccan businesses remain under credit constraints. In this context, [20]find that more organized companies have a greater probability of access to formal credit. Indeed, the results of their study indicate that the size of the company and the educational level of the owners are positively associated with access to formal credit. So in accordance with the existing literature on credit constraints for small businesses, as well as those related to the determinants of the formalization of informal production units, we find that informal micro units with difficulty accessing formal financing are less willing to move to the formal sector. In this perspective, (Feltenstein and Shamloo 2013) point out that taking into account the specific needs of the informal sector for access to sources of formal finance can determine the levels of compliance of companies.

Thus, using a panel of administrative data and regression discontinuity analyzes, [13]focused their analysis on the eligibility thresholds for a new tax system. Indeed, they examined how the introduction of preferential tax regimes for Georgian micro and small businesses in 2010 affects official establishment and tax compliance. Their results show that this new tax regime for microenterprises increased the number of formal enterprises from $18 \%$ to $30 \%$. Therefore, they find that tax policy and administration is probably an important instrument affecting the formalization decisions of companies and their associated growth potential.

In Morocco, it is also assumed that higher tax rates lead to greater informality. In this sense, the results of the field study carried out by [24]with a sample of actors operating in the derbghallef and derbomar markets revealed that informal entrepreneurs consider the fiscal framework and over-regulation as obstacles to entrepreneurship in the formal sector, and in the first place demand state actions aimed at lowering taxes. In this sense, [6]also decide that non-compliance with tax rules stems from the complexity of the tax system

As for [17], he finds that among the 72 unregistered companies, $43 \%$, or 31 out of 72 of the bosses regret the complexity of the official procedures aimed at registering a company. Working on 23,084 registered SMEs in 86 countries, [7] confirm that a poor quality of the institutional environment increases the size of the informal economy, increases costs and decreases the benefits attributed to the decision to formalize and, moreover, creates a "culture of informality". Conversely, when the rule of law is effective, informal enterprises have less incentive to expand their activities for fear of detection. During the same year, on the one hand, the results of the estimate of [21]indicate that the popularization of declaration procedures are important levers of formalization. On the other hand, those of [29]point out that cumbersome regulation is significantly associated with a low probability of doing business formally. Indeed, the results of these authors are consistent with studies that highlight the importance of improving the quality of the institutional environment, especially in less developed economies where the informal sector is important.

\section{Research methodology}

In order to test the hypothesis of the effect of the business climate on the disposition of the Moroccan informal micro-entrepreneur to switch to the formal sector, we resort to the use of a multivariate dependency test method such as stepwise logistic regression. Since our hypothesis is not based on a precise variable but on a combination of variables, this method makes it possible to reduce the number of variables and to keep only those which are involved in the variable to be explained.

As part of this work, the field survey related to the desire of formalization covered 100 micro-entrepreneurs carrying out illegal and clandestine activities, and for which we do not have official registers to obtain their contact details. Thus, it is only a meticulous research that allowed us to reach respondents.

Thus, we first contacted all our acquaintances (personal contacts) who had match the requirements set for our study, and those who were likely to know them. Subsequently we focused on the non-probability sampling method by reasoned choice (snowball technique). This technique «consists of finding a first respondent who checks the selection criteria defined by the researcher. We ask this first interlocutor to designate another, who will also be likely to have the required characteristics, and so on » (Thiétart, 2007).

This is a sampling method that makes it possible to choose the elements of the sample more precisely. In addition, it easily guarantees compliance with certain search criteria such as homogeneity. 


\section{Presentation and discussion of research results}

This part presents the results of the econometric analysis of the factors associated with the business environment and the determinants of the transition from the informal to the formal.

Table 1: The sub-variables of the business environment.

\begin{tabular}{|l|l|l|l|l|}
\hline Sub variables & Effect & Sign & P (|zl) & link \\
\hline $\begin{array}{l}\text { employee training } \\
\text { and competence }\end{array}$ & $-3,37078$ & - & 0,07737 & Low \\
\hline $\begin{array}{l}\text { insufficient } \\
\text { support structures }\end{array}$ & $-2,48816$ & - & 0,01833 & Strong \\
\hline $\begin{array}{l}\text { Access to the } \\
\text { premises }\end{array}$ & $-2,48127$ & - & 0,00107 & $\begin{array}{l}\text { Verystr } \\
\text { ong }\end{array}$ \\
\hline $\begin{array}{l}\text { lack of } \\
\text { information }\end{array}$ & $-2,35197$ & - & 0,004 & $\begin{array}{l}\text { Verystr } \\
\text { ong }\end{array}$ \\
\hline $\begin{array}{l}\text { Procedures and } \\
\text { authorizations }\end{array}$ & $-2,18461$ & - & 0,0031 & $\begin{array}{l}\text { Verystr } \\
\text { ong }\end{array}$ \\
\hline $\begin{array}{l}\text { access to finance } \\
\text { Access to } \\
\text { property and } \\
\text { public services }\end{array}$ & $-1,85558$ & - & 0,00835 & $\begin{array}{l}\text { Verystr } \\
\text { ong }\end{array}$ \\
\hline $\begin{array}{l}\text { access to the } \\
\text { public market }\end{array}$ & $-1,74971$ & - & 0,02053 & Strong \\
\hline registration cost & $-1,55437$ & - & 0,04072 & Strong \\
\hline $\begin{array}{l}\text { tax rate } \\
\text { and }\end{array}$ & $-1,15797$ & - & 0,1022 & Strong \\
\hline
\end{tabular}

Source: Author's calculation from survey data.

The link is deduced by thresholds of $\mathrm{P}(|\mathrm{z}|)$ \{Very strong $<0.001$, Strong $<0.01$, Average $<0.05$, Very weak $<0.1)$; The sign indicates the direction of influence the positive is proportional and the negative is inversely proportional\}; the effect presents the coefficient of the variable in the regression formula.

Formalization is blocked by difficult access to premises for informal microenterprises. This result is similar to that of [11]who showed that the local is particularly problematic for informal enterprises. There are two possible reasons for this. First, to acquire premises, title must be transferred to the new owner, which requires interaction with government officials, which an informal business tends to avoid. Second, often, to avoid interactions with officials, informal businesses need to be more mobile and not tied to a fixed location. As a result, they do not have one place, which can discourage their investments and subsequently their productivity and growth.

Regarding the limited access to information, the results show that it negatively impacts the desire for formalization. Indeed, involvement in the informal sector is linked to ignorance of the rules for setting up and operating businesses, insofar as a better knowledge of the rules of the game would favor the choice of formalization.
These results are similar to those of (E. Ouedraogo et al., 2011) and (Gautier, 2001) which show that information asymmetry seems important in the explanation of tax evasion by micro entrepreneurs.

As for the cumbersome administrative and authorization procedures, it has a negative impact on the desire of formalization. This result corroborates that of [7]who confirm that a poor quality of the institutional environment increases the size of the informal economy, increases costs and decreases the benefits attributed to the decision to formalize.

Problems of access to finance, markets and public goods and services negatively impact the desire of formalization. This argument is reinforced by [23] who indicates that informal entrepreneurs are motivated to register when they that formal enterprises have many advantages, in particular better access to finance, raw materials, infrastructure and utilities as well as facilities to give receipts to customers to attract them.

The results also show that the cost of registration is very high and reduces the chance that an informal microentrepreneur formalizes his business. This is because the capital available for informal micro-entrepreneurs at the start of their entrepreneurial project at the start of the business is relatively low. Therefore, the cost of recording in terms of money and / or time would jeopardize his project. This result corroborates that of (WB 2011) who observes that regressive compliance costs can determine the compliance levels of companies.

The inadequacy of support structures seriously blocks the desire to formalize micro-enterprises. Hence the importance of increasing awareness of the registration procedure and of emphasizing the usefulness of various assistance programs, particularly in terms of promoting the transition from informal firms to a more professional status, formal [2]; [6].

Tax rates also impact the decision of formalization. This can be explained by the fact that taxes constitute a burden on the company which diminishes its profit, while it is based on the motive of maximizing profit. This result corroborates that of [11] who confirms that the decision to formalize is negatively correlated with the tax rate. Late, the results of the estimation of a probit model by [21] indicate that the introduction of an incentive tax is one of the important keys to formalization.

\section{Conclusion}

For entrepreneurs with completely or partially informal activities, but without intention of moving to the formal, the pretexts are linked to the perception of many disadvantages: limited access to premises, basic infrastructure, information, etc. They are also worried about losing the acquired social benefits and paying taxes if they formalized. These are usually young people who need an income to support the family. However, they would like to formalize once they have received financial and / or administrative support.

Between " let it be ", eradication, deregulation or the facilitation of formalization, we believe that the latter path is the dominant approach in public policies today. Indeed, 
if governments want to legitimize informal entrepreneurship rather than eradicate it, improving the business environment is one of the first areas to be taken into account when implementing reforms.

Following the results of our study, we are making a set of proposals and recommendations along several axes aimed firstly at cleaning up the general business climate in Morocco and secondly at promoting youth entrepreneurship. This involves in particular easing the financing constraint by improving the offer, strengthening loan guarantees ... alleviating the problem of land by increasing the number of incubators, developing industrial areas dedicated to young people ... Likewise, the simplification of the procedures and formalities of creation by establishing real one-stop shops, the easing of the fiscal and social pressure, the ease of access to information and to basic infrastructures are all avenues that provide for informal enterprises a cheaper transition to the formal sector.

We also underline the importance for entrepreneurship support programs in Morocco to take into account, in their support policies, the systems in which informal microentrepreneurs are inserted. Indeed, the heterogeneity of the socio-economic contexts in which the informal sector operators operate shows that these actors do not need the same form of support, as well as the promotion of microcredit policies or non-financial support for entrepreneurship, is probably only relevant for a minority of the target population.

\section{References}

1. ALAMI, R. M. (2016). LES JEUNES ET L'INFORMEL AU MAROC. Maroc.

2. Benjamin, N., Diop, T., Golub, S., \& Mbaye, A. (2012). Les entreprises informelles de 1' Afrique de 1 ' ouest francophone. Taille, productivité et institutions.

3. Berrou, J. (2014). Entrepreneurs du secteur informel. Presses de Sciences Po (P.F.N.S.P.). Retrieved from http://www.cairn.info/dictionnaire-sociologique-de$1-$ 227.htm\%0A entrepreneuriat--9782724616408-page-

4. Braun, J., \& Loayza, N. V. (1994). Taxation, Public services, and the informal sector in a model of endogeneous growth. World Bank, Policy Research.

5. Charmes, J., \& Adair, P. (2014). L'inconstant caméléon, ou comment appréhender l'informel? Mondes En Développement, 2(n`166), 7-16.

6. Cling, J. P., Lagrée, S., Razafindrakoto, M., \& Roubaud, F. (2012). L'économie informelle dans les pays en developpement.

7. Distinguin, I., Rugemintwari, C., \& Tacneng, R. (2016). Can Informal Firms Hurt Registered SMEs ' Access to Credit? WORLD DEVELOPMENT, $x x$. https://doi.org/10.1016/j.worlddev.2016.04.006

8. Farrell, D. (2004). The hidden dangers of the informal economy. McKinsey Quarterly 3., (4), 3647.
9. Galiani, S., Meléndez, M., \& Navajas., C. (2015). ON THE EFFECT OF THE COSTS OF OPERATING FORMALLY: Working Paper 21292. Retrieved from http://www.nber.org/papers/w21292

10. HCP. (2018). Enquete nationale sur le secteur informel 2013/2014.

11. Ingram, M., Vijaya, R., \& Vyjayanti, D. (2007). Why Do Firms Choose to be Informal? Evidence from Enterprise Surveys in Africa. Washington, Banque Mondiale, (September), 1-46.

12. Ishengoma, E., \& Kappel, R. (2006). Economic Growth and Poverty: Does Formalisation of Informal Enterprises Matter?

13. Jan, L., \& Miriam, B. (2014). Small Business Tax Policy, Informality, and Tax Evasion Evidence from Georgia. Policy Research Working Paper, (August).

14. Johnson, S., Kaufmann, D., \& Zoido-Lobatón, P. (1998). Regulatory Discretion and the Unofficial Economy. American Economic Review, 88(2), 387392. https://doi.org/10.2307/116953

15. Kervyn de Lettenhove, M., \& Lemaître, A. (2018). Micro-entreprises du secteur informel dans le Mono (Bénin) : vers un approfondissement à travers une approche d'économie populaire. Mondes En Développement, 181(1), 11. https://doi.org/10.3917/med.181.0011

16. Klein, E., \& Tokman, V. E. (1993). INFORMAL SECTOR AND REGULATIONS IN ECUADOR AND JAMAICA (Vol. 86).

17. Kraiem, M. (2015). Les dynamisations des microentreprises dans les PMA: une relecture de l' économie informelle manufacturière au Mali. Universit' e de Versailles- Saint Quentin en Yvelines.

18. McPherson, M. A., \& Liedholm, C. (1996). Determinants of Small and Micro Enterprise Registration: Results from Surveys in Niger and Swaziland. World Development, 24(3), 481-487. https://doi.org/10.1016/0305-750X(95)00147-5

19. Mead, D. C., \& Morrisson, C. (1996). The Informal Sector Elephant. World Development, 24(30), 32.

20. Nikaido, Y., Pais, J., \& Sarma, M. (2015). What hinders and what enhances small enterprises ' access to formal credit in India? Journal of Advanced Research, 5(1), 43-52. https://doi.org/10.1016/j.rdf.2015.05.002

21. Nohoua, T. (2016). Les déterminants de la disposition des managers à formaliser les PME informelles en Côte d' Ivoire. Études Caribéennes 35, 0-32. https://doi.org/10.4000/etudescaribeennes.10358

22. OIT. (1972). Employment, Incomes and equality: a strategy for increasing productive employment in Kenya, 593. https://doi.org/http://dx.doi.org/10.1016/j.cplett.201 5.04.006

23. Ouedraogo, M. F. (2015). Les déterminants du secteur informel dans les pays en voie de développement: réglementation, corruption, procédures administratives et mode de financement 
24. Redouane, B. R. M. (2014). Le micro entrepreneuriat dans le secteur informel marocain. Colloque Ethique, Entrepreneuriat et Développement.

25. Schneider, F. (2005). Shadow economies around the world: What do we really know? European Journal of Political Economy, 21(3), 598-642. https://doi.org/10.1016/j.ejpoleco.2004.10.002

26. Schneider, F., \& Enste, D. H. (2000). Shadow Economies: Size, Causes, and Consequences. Journal of Economic Literature, 38(1), 77-114. https://doi.org/10.1257/jel.38.1.77

27. Torrès, O. (2002). Essai de conceptualisation proxémique de la petitesse des entreprises. 6ème Congrès International Francophone PME (CIFPME 2002), 1-18.

28. W. Webb, J., D. Bruton, G., Tihanyi, L., \& Ireland, R. D. (2012). Research on entrepreneurship in the informal economy: Framing a research agenda. Journal of Business Venturing, 1-17. https://doi.org/10.1016/j.jbusvent.2012.05.003

29. Williams, C. C., Shahid, M. S., \& Marti, A. (2016). Determinants of the Level of Informality of Informal Micro-Enterprises : Some Evidence from the City of Lahore, Pakistan. World Development Vol., 84, 312325. https://doi.org/10.1016/j.worlddev.2015.09.003 